\title{
Serum concentrations of oestradiol and progesterone, and sexual behaviour during the normal oestrous cycle in the leopard (Panthera pardus)
}

\author{
A. M. Schmidt, D. L. Hess*, M. J. Schmidt, R. C. Smith $†$ and C. R. Lewis \\ Washington Park Zoo, 4001 S.W. Canyon Rd, Portland, Oregon 97221; \\ *Oregon Regional Primate Research Center, 505 N.W. 185th Ave., Beaverton, Oregon 97006; and \\ $\nmid$ Point Defiance Zoo \& Aquarium, 5400 N. Pearl St, Tacoma, Washington 98407, U.S.A.
}

\begin{abstract}
Summary. Three mature nulliparous female leopards were studied for 5 years. During three separate 6-month periods serum oestradiol and progesterone concentrations were measured at weekly intervals. Oestradiol was elevated over $21 \mathrm{pg} / \mathrm{ml}$ for 54 weeks during these 3 periods, and 36 oestradiol peaks $(65.8 \pm 6.3 \mathrm{pg} / \mathrm{ml}$ (mean \pm s.e.m.), range $21-172 \mathrm{pg} / \mathrm{ml}$ ) were identified. Daily frequency of feline reproductive behaviours averaged over each week increased from $1.9 \pm 0.2(n=93)$ during weeks with low serum oestradiol concentrations $(<21 \mathrm{pg} / \mathrm{ml})$ to $5 \cdot 3 \pm 0 \cdot 6(n=54)$ during weeks when serum oestradiol concentrations $(>21 \mathrm{pg} / \mathrm{ml})$ were high.

Increased serum progesterone concentrations $(13-98 \mathrm{n} / \mathrm{gml})$ were observed on 5 occasions in 2 leopards housed together. These presumptive luteal phases lasted from 1 to 5 weeks. Baseline progesterone values were $1.6 \pm 0.4 \mathrm{ng} / \mathrm{ml}(n=131)$. No progesterone increments were observed in isolated animals, and serum concentrations remained at baseline levels. These limited observations suggest that female leopards do not require intromission to induce ovulation and luteal function.

The average interval between oestradiol peaks for cycles with no progesterone increment was 3.4 weeks (range 1-6 weeks). The interval for the 3 complete cycles associated with elevated progesterone concentrations was $7 \cdot 3$ weeks. Analysis of sexual behaviours over the 5-year study period revealed no evidence of seasonality in these captive leopards.
\end{abstract}

Keywords: oestradiol; progesterone; behaviour; leopard; oestrous cycle

\section{Introduction}

The analysis of serum steroid hormones during the various phases of the reproductive cycle in different members of the family Felidae has led to a better understanding of the normal reproductive cycle in these species. Steroid patterns recorded in domestic cats indicate that multiple oestradiol peaks occur during the poly-oestrous season, but that progesterone secretion is not evident without exposure to a male (Paape et al., 1975; Verhage et al., 1976). The domestic cat is a reflex ovulator (Longley, 1910), and copulation or cervical stimulation will induce ovulation (Greulich, 1934). Reproductive behaviour is correlated with stages of the oestrous cycle and is hormone dependent since such behaviour disappears with ovariectomy (Michael, 1961; Leyhausen, 1979; Shille et al., 1979). Similar hormonal data have been collected from females of other members of the family Felidae. In most studies females were examined as isolated individuals without concurrent male exposure; for example, a single jaguar (Wildt et al., 1979), isolated pumas (Bonney et al., 1980), or isolated Siberian tigers (Seal et al., 1985). In none of these cases was any increment in progesterone release suggestive of ovulation recorded, despite marked alterations in oestradiol secretion, unless the animals were given hormonal therapy. In contrast, progesterone surges suggestive of ovulation were recorded after $6 / 8$ oestradiol increases in 3 female lions isolated from males, but housed 
together (Schmidt et al., 1979). These data provided the initial evidence that not all felines are strict induced ovulators.

Information about the reproductive cycle of leopards has been limited to observations of external events based on copulation (Sadleir, 1966a, b; Eaton, 1977). Hormonal data are, to our knowledge, not available. This study was undertaken to provide information on serum oestradiol and progesterone concentrations during the normal cycle, and to correlate any observed changes in reproductive behaviours with changes in oestradiol concentrations. In addition, we hoped to determine whether the leopards would develop a functional corpus luteum in the absence of a male.

\section{Materials and Methods}

This study was conducted over a 5-year period. The 3 mature nuliparous female leopards observed were housed in the feline building of the Washington Park Zoo in Portland, Oregon, U.S.A. The Zoo did not keep any male leopards during this study.

For the first 3 years of the study Leopards B and C were exhibited together daily in an outdoor area measuring $15.5 \times 7.1 \mathrm{~m}$. At the end of that 3-year period, Leopard B was exchanged for the third female, $\mathrm{K}$, through another zoo, and for the last 2 years of the study Leopards $\mathrm{C}$ and $\mathrm{K}$ were exhibited and housed alone with auditory, visual and olfactory contact, but without opportunity for physical contact. They alternated in the same outside area every other day, and were fed and held in adjacent indoor areas $(2.3 \times 4.8 \mathrm{~m}$ and $2.1 \times 2.9 \mathrm{~m})$. Commercial carnivore diet (Nebraska Brand Feline Diet, Animal Spectrum, In., Lincoln, NE, U.S.A.) was fed 6 times per week. Water was available ad libitum.

For three 6-month periods, separated by variable intervals, blood samples were collected once per week, and serum was frozen for later analyses of oestradiol and progesterone as described previously (Schmidt et al., 1979). Leopards were immobilized with ketamine $\mathrm{HCl}(12-14 \mathrm{mg} / \mathrm{kg})$ and xylazine $(0.5-1 \mathrm{mg} / \mathrm{kg})$ by darting.

Leopards were observed for 45-min periods in the outdoor area every day for the 5-year study period except for the days on which serum samples were collected. Behaviour patterns were recorded in 1-min block periods. Each behaviour was scored by the number of blocks in which it occurred. These daily behavioural data were averaged for each week by summing the daily frequency of each behaviour for the 3 days before and after the day of serum collection, then dividing by the number of observation days for the week.

Daily frequencies of those behaviours generally agreed upon as characteristic feline reproductive behaviour (Cooper, 1942; Michael, 1961; Ulmer, 1966; Schaller, 1967, 1972; Kleiman, 1974; Leyhausen, 1979; Schmidt et al., 1979; Shille et al., 1979; Seal et al., 1985) were examined to see which, if any, were consistently associated with hormonal oestrus in our leopards (see 'Results' section). Average daily frequencies of behaviours were compared during weeks of high oestradiol $(>21 \mathrm{pg} / \mathrm{ml})$, and low oestradiol $(<21 \mathrm{pg} / \mathrm{ml})$ concentrations. This value $(21 \mathrm{pg} / \mathrm{ml}) \mathrm{was}$ arbitrarily selected before behaviour analysis based on examination of the total data set and the apparent grouping of values above and below this point; in addition $21 \mathrm{pg} / \mathrm{ml}$ was the lowest peak oestradiol concentration recorded which was followed by a progesterone rise demonstrating the occurrence of ovulation.

Oestradiol and progesterone concentrations were measured as described previously (Schmidt et al., 1979) using antisera purchased from Holly Hills Biologicals (Hillsboro, OR, U.S.A.). The oestradiol antiserum was raised against 6-keto oestradiol-17 $\beta$-6-oxime-BSA in rabbits and cross-reacted $28 \%$ with oestrone, $3 \%$ with oestriol and $<1 \%$ with common androgens, progestagens and corticoids. The progesterone antiserum was similarly raised against $11 \alpha$-hydroxyprogesterone-1 $1 \alpha$-hemisuccinate-BSA and cross-reacted $2 \%$ with $17 \alpha$ - and $20 \alpha$-hydroxyprogesterone, desoxycorticosterone and $<1 \%$ with other common androgens, oestrogens and corticoids. Chromatography (Resko et al., 1975) on 1.0 gram LH-20 columns separated oestrone, oestradiol and progesterone from each other as well as from common androgens and corticoids before assay. Various aliquants of pooled leopard serum were assayed after chromatography and provided parallel displacement curves to the standards in both assays. Addition of $25 \mathrm{pg}$ oestradiol $/ \mathrm{ml}$ and $12.5 \mathrm{ng}$ progesterone $/ \mathrm{ml}$ to pools of leopard serum yielded recoveries of $23.6 \mathrm{pg} / \mathrm{ml} \mathrm{and} 12 \cdot 2 \mathrm{ng} / \mathrm{ml}$ after subtraction of pre-existing steroid levels. Serum $(100-500 \mu \mathrm{l})$ was extracted with freshly distilled diethylether and analysed for steroid content by radioimmunoassay after chromatographic purification. The values derived from the standard curve were corrected for reagent blanks and extraction/purification losses during chromatography on $1 \cdot 0$ gram Sephadex LH-20 columns. Average blank and recovery factors were monitored in independent samples and were found to be $2 \cdot 1 \pm 0.9 \mathrm{pg}$ and $72.3 \pm 1.4 \%$ for the oestradiol assay and $26.5 \pm 4.2 \mathrm{pg}$ and $83.4 \pm 0.8 \%$ for the progesterone assay. The limits of sample detection after correction were $2 \mathrm{pg} / \mathrm{tube}$ for oestradiol and $10-15 \mathrm{pg} / \mathrm{tube}$ for progesterone. The within- and between-assay coefficients of variation for either assay did not exceed $12 \%$ as determined by repeated analysis of our standard quality control pools of rhesus monkey serum.

\section{Oestradiol concentrations}

\section{Results}

During the three 6-month collection periods 36 oestradiol peaks suggestive of oestrus were recorded $(65.8 \pm 6.3 \mathrm{pg} / \mathrm{ml}$; range $21-172 \mathrm{pg} / \mathrm{ml}$ ) (Figs 1 \& 2). Oestradiol concentrations were 
(a) Leopard B
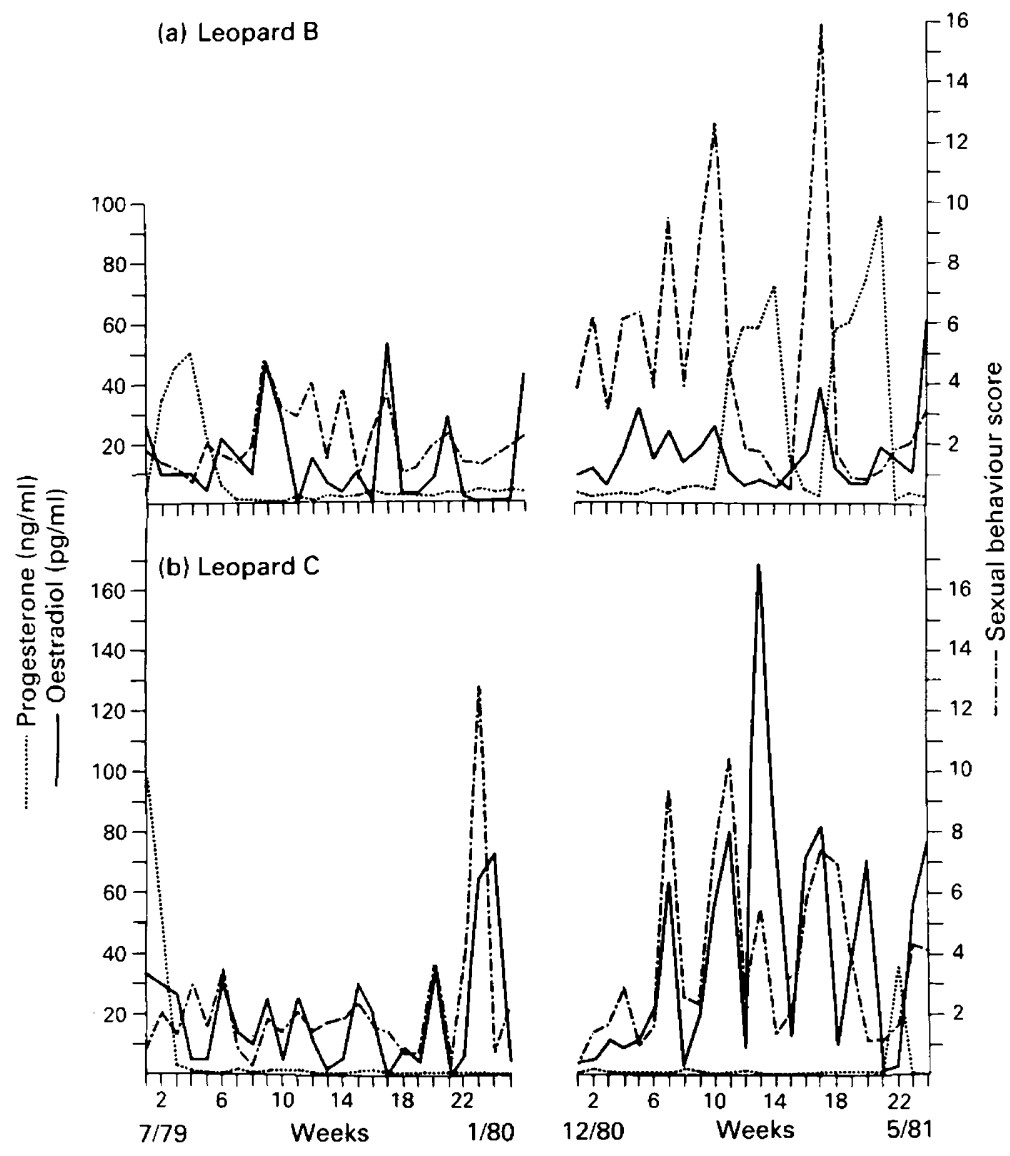

Fig. 1. Weekly oestradiol, progesterone and sexual behaviour scores for Leopards B (a) and C (b) while housed together.

consistently higher during the cycles of Leopard $\mathrm{C}(72.7 \mathrm{pg} / \mathrm{ml})$ than during those of the other 2 leopards $(36.1 \mathrm{pg} / \mathrm{ml})$. Intervals between oestradiol peaks averaged 3.4 weeks for cycles with no progesterone increase (range 1-6 weeks; $n=33$ ), and 7.3 weeks (range 7-8 weeks; $n=3$ ) for cycles with a luteal phase; varying within as well as between individuals. Because of the intermittent sampling schedule true maximum serum concentrations during the observed oestradiol surges were probably missed in many cases.

\section{Progesterone concentrations}

Increments in serum progesterone $(13-98 \mathrm{ng} / \mathrm{ml})$ were recorded 5 times while leopards were housed together (Fig. 1). In contrast, similar progesterone increments were not observed in the 2 isolated animals (Fig. 2). For Leopard B (Fig. la) the entire course of progesterone secretion was recorded 3 times, and was consistently $4-5$ weeks in duration. In Leopard C (Fig. 1b) progesterone concentrations were already elevated as the first serum collection period began, and this luteal phase ended 2 weeks later. In the second observation period progesterone reached $36 \mathrm{ng} / \mathrm{ml}$ for 1 week. Progesterone concentrations for this animal were otherwise quite low $(0.8 \pm 0.5 \mathrm{ng} / \mathrm{ml})$. Baseline progesterone values for all females averaged $1.6 \pm 0.3 \mathrm{ng} / \mathrm{ml}(n=131)$. 

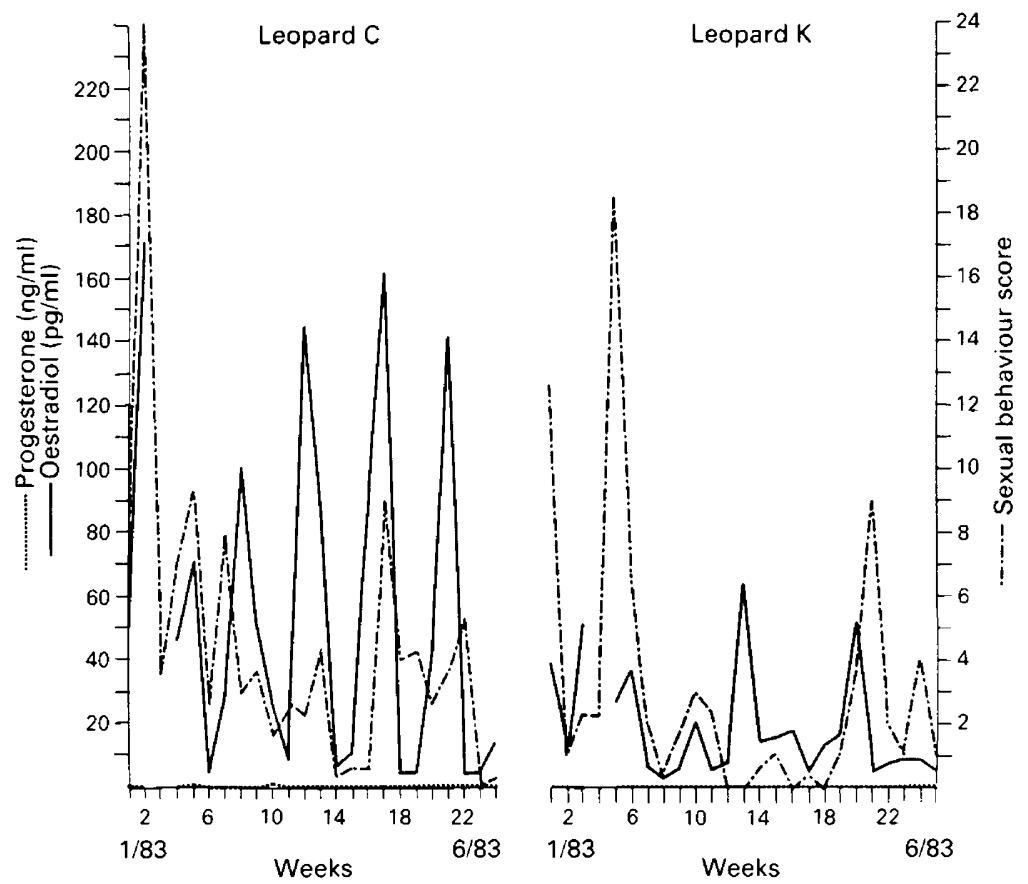

Fig. 2. Weekly oestradiol, progesterone and sexual behaviour scores for Leopards $\mathbf{C}$ and $\mathbf{K}$ while housed alone. Blood samples were not collected for 1 week during the sampling period.

Table 1. Mean daily sexual behaviour scores during weeks when high oestradiol ( $>21 \mathrm{pg} / \mathrm{ml})$, low oestradiol $(<21 \mathrm{pg} / \mathrm{ml})$, or high progesterone $(>10 \mathrm{ng} / \mathrm{ml})$ concentrations were recorded

\begin{tabular}{|c|c|c|c|c|c|}
\hline \multirow[b]{2}{*}{ Condition } & \multicolumn{2}{|c|}{ Leopards housed together } & \multicolumn{2}{|c|}{ Leopards housed alone } & \multirow{2}{*}{$\begin{array}{l}\text { Mean of all } \\
3 \text { leopards }\end{array}$} \\
\hline & Leopard C & Leopard B & Leopard C & Leopard $\mathrm{K}$ & \\
\hline High oestradiol & $4.1 \pm 0.7(19)$ & $4 \cdot 9 \pm 1 \cdot 2(14)$ & $6 \cdot 3 \pm 1 \cdot 6(14)$ & $6 \cdot 6 \pm 2 \cdot 5(7)$ & $5 \cdot 3 \pm 0.6$ \\
\hline Low oestradiol & $1.9 \pm 0.3(31)$ & $2 \cdot 1 \pm 0.4(36)$ & $2.3 \pm 0.7$ & $1.6 \pm 0.5(17)$ & $1.9 \pm 0.2(93)$ \\
\hline High progesterone & $2.5 \pm 0.7$ & $1 \cdot 3 \pm 0 \cdot 3(13)$ & & & $1.5 \pm 0.3(16)$ \\
\hline
\end{tabular}

Values are mean \pm s.e.m. for no. of observation weeks in parentheses.

\section{Behaviour}

Mean daily frequencies of feline reproductive behaviours were compared during weeks of high and low serum oestradiol concentrations. The frequency of all activity for our leopards, like most felines, was low. Although no single behaviour was consistently associated with elevated oestradiol, several feline reproductive behaviours tended to increase as oestradiol values increased, and when combined gave a good indication of oestrus (Table 1).

Those behaviours that were consistently elevated during weeks of high oestradiol concentrations were summed for each week of the study and termed the 'sexual behaviour score'. These behaviours included: rolling, rubbing head, rubbing perineal area (on another leopard), lordosis, mounting, being mounted, 'getting under' (one female lifts the abdomen of the other with her head), a characteristic low growl, auto-grooming, urinating, activity, and 'sawing' (leopard roar). 
In animals housed alone social reproductive behaviours (mounting, being mounted, 'getting under', and rubbing perineal area) were not observed, and neither was lordosis. In animals housed together 'sawing' was heard only once in 3 years, but was heard frequently in isolated animals during hormonal oestrus.

Average daily sexual behaviour scores were graphed weekly for the 5-year period (data not shown). Intervals between peak sexual behaviour scores did not provide any evidence of seasonality for oestrus in any of the 3 leopards. The pattern of sexual behaviour scores was consistent whether or not serum was collected.

\section{Discussion}

The oestradiol profile shown by our leopards is similar to profiles determined for other felines. In the follicular phase of the oestrous cycle oestradiol secretion repeatedly increased for brief periods (average peak of $65.8 \mathrm{pg} / \mathrm{ml}$ ), then fell rapidly to baseline values (Figs $1 \& 2$ ). These values compare with $46.7 \mathrm{pg} / \mathrm{ml}$ for Siberian tigers (Seal et al., 1985), 19-108 pg/ml for lions (Schmidt et al., 1979), $30-375 \mathrm{pg} / \mathrm{ml}$ for pumas (Bonney et al., 1980), and $58 \mathrm{pg} / \mathrm{ml}$ for domestic cats (Verhage et al., 1976). Intervals between oestradiol peaks with no progesterone increase ( 3.4 weeks) were similar to 21 days reported for leopard cycles with no breeding (Eaton, 1977), and intervals between oestradiol peaks with a luteal phase ( $7 \cdot 3$ weeks) were similar to $45 \cdot 8$ days (Sadleir, 1966b) and 52.6 days (Eaton, 1977) reported for leopard cycles with breeding observed.

The progesterone profile observed in our leopards did not always follow a consistent pattern. At times (Fig. 2) the pattern was typical of unmated domestic cats, consisting of closely-timed oestradiol surges uninterrupted by ovulation and increased progesterone secretion (Paape et al., 1975; Verhage et al., 1976; Shille et al., 1979), but on other occasions (Fig. 1) a luteal phase was observed, which seemed dependent on contact with another animal since it occurred only in females housed together. Elevated progesterone concentrations were detected 3 times in Leopard $\mathbf{B}$ and she was observed being mounted by her female cagemate 6 and 17 times on two occasions in the week of high oestradiol before two of the luteal phases, suggesting that this may have been sufficient stimulus to trigger ovulation. However, 9 other oestradiol surges were recorded, some when Leopard B was observed being mounted, with no resulting increase in progesterone concentration. Evidently, although ovulation does not usually accompany an oestrus without mating in leopards, ovulation may occur without full mounting and intromissive stimulation in this species. The duration of elevated progesterone concentrations was shortened in our leopards ( $1-5$ weeks) compared to ovulating non-pregnant domestic cats (6 weeks), and may reflect deficient luteal function.

Within the family Felidae, with the exception of the lion, development of a luteal phase has not previously been observed in the absence of a male. In female domestic cats housed together progesterone does not increase after oestrus without physical contact with a male cat (Paape et al., 1975; Verhage et al., 1976) or suitable cervical stimulation (Greulich, 1934). In recent studies 10/48 (Wildt et al., 1980), 9/18 (Concannon et al., 1980) and 1/3 (Glover et al., 1985) domestic cats ovulated if allowed only one copulation on Days 1-4 of oestrus. Glover et al. (1985) found 3/3 cats ovulated with one copulation on Days 4-5: 85-100\% of the cats ovulated if allowed 3 or more copulations regardless of the day of oestrus. A slight increase in LH was measured in cats mounted by a male with no intromission, but it was much lower than $\mathrm{LH}$ after mating with intromission (Concannon et al., 1980) and did not lead to ovulation and progesterone secretion. Serum concentrations of up to $36 \mathrm{ng}$ progesterone $/ \mathrm{ml}$ were achieved in domestic cats after repeated matings with a vasectomized male, and remained elevated for about 40 days (Paape et al., 1975; Verhage et al., 1976). Ferrets, which also ovulate reflexly, will not ovulate if males are allowed to mount and neck grip in the absence of intromission (Carroll et al., 1985).

Isolated female pumas produced progesterone at baseline levels $(<2 \mathrm{ng} / \mathrm{ml})$ unless given hCG, when progesterone increased to $150-300 \mathrm{ng} / \mathrm{ml}$ in non-pregnant and pregnant animals, and 
remained elevated for 45-50 days even in the non-pregnant animal (Bonney et al., 1980). Similarly, a female jaguar had progesterone concentrations of $<5 \mathrm{ng} / \mathrm{ml}$ unless stimulated with hCG or LHRH, whereupon progesterone rose to $11-22 \mathrm{ng} / \mathrm{ml}$ (Wildt et al., 1979). In both studies ovulation was confirmed by laparoscopy. In isolated female Siberian tigers progesterone values remained at baseline levels $(1 \cdot 2 \pm 0 \cdot 15 \mathrm{ng} / \mathrm{ml})$ during repeated oestrous cycles (Seal et al., 1985). Female lions housed together, but with no physical contact with males, produced progesterone increases (17$282 \mathrm{ng} / \mathrm{ml}$ ) after $6 / 8$ oestradiol surges, the luteal phases lasting $2-6$ weeks. Recent ovulation sites were observed on the ovaries of one lion isolated for 1 month before a complete ovariohysterectomy which was performed 2 weeks after the occurrence of hormonal and behavioural oestrus (Schmidt et al., 1979).

The behaviour of our leopards in oestrus was similar to that described for lions (Cooper, 1942; Schaller, 1972; Schmidt et al., 1979), tigers (Kleiman, 1974; Seal et al., 1985), and domestic cats (Michael, 1961; Leyhausen, 1979; Shille et al., 1979), although individual variation was clear. Hormonal oestrus was not always accompanied by observable behavioural oestrus, but behavioural oestrus was not observed without a concurrent increase in serum oestradiol concentrations.

Throughout the family Felidae a spectrum of male/female interactions which result in ovulation and corpus luteum function (as judged by serum progesterone concentrations) has been observed. At one end of the spectrum domestic cats require repeated physical contact and cervical stimulation by a male to induce ovulation and luteal progesterone increments, while at the other lions apparently ovulate with no physical contact with a male, or in a single case, without any physical contact with a conspecific. In an intermediate position, leopards demonstrated a luteal phase when in physical contact with another female, but did not ovulate when isolated.

We thank J. S. McCusker, then general curator of the Washington Park Zoo, for procuring the 3rd leopard for this study. This work was supported in part by NIH grants RR-00163 and HD 18185.

\section{References}

Bonney, R.C., Moore, H.D.M. \& Jones, D.M. (1980) Plasma concentrations of oestradiol-17ß and progesterone, and laparoscopic observations of the ovary in the puma (Felis concolor) during oestrus, pseudopregnancy and pregnancy. J. Reprod. Fert. 63, 523-531.

Carroll, R.S., Erskine, M.S., Doherty, P.C., Lundell, L.A. \& Baum, M.J. (1985) Coital stimuli controlling luteinizing hormone secretion and ovulation in the female ferret. Biol. Reprod. 32, 925-933.

Concannon, P., Hodgson, B. \& Lein, D. (1980) Reflex LH release in estrous cats following single and multiple copulations. Biol. Reprod. 23, 111-117.

Cooper, J.B. (1942) An exploratory study of African lions. Comp. Psychol. Monogr. 17, 1-49.

Eaton, R.L. (1977) Reproductive biology of the leopard. Zool. Garten, 47, 329-351.

Glover, T.E., Watson, P.F. \& Bonney, R.C. (1985) Observations on variability in $\mathrm{LH}$ release and fertility during oestrus in the domestic cat (Felis catus). $J$. Reprod. Fert. 75, 145-152.

Greulich, W.W. (1934) Artificially induced ovulation in the cat (Felis domestica). Anat. Rec. 58, 217-224.

Kleiman, D.G. (1974) The estrous cycle in the tiger (Panthera tigris). In The World's Cats, vol. 2, pp. 60-75. Metropolitan Printing Co., Portland.
Leyhausen, P. (1979) Cat Behavior. Garland STPM Press, New York.

Longley, W.H. (1910) Factors which influence the maturation of the egg and ovulation in the domestic cat. Science, N.Y. 31, 465-466.

Michael, R.P. (1961) Observation upon the sexual behaviour of the domestic cat (Felis cattus L.) under laboratory conditions. Behaviour 18, 1-24.

Paape, S.R., Shille, V.M., Seto, H. \& Stabenfeldt, G.H. (1975) Luteal activity in the pseudopregnant cat. Biol. Reprod. 13, 470-474.

Resko, J.A., Ploem, J.G. \& Stadelman, J.L. (1975) Estrogens in fetal and maternal plasma of the rhesus monkey. Endocrinology 97, 425-430.

Sadleir, R.M.F.S (1966a) Investigation into the reproduction of larger Felidae in captivity. J. Reprod. Fert. 12, 411, Abstr.

Sadleir, R.M.F.S. (1966b) Notes on reproduction in the larger Felidae. Int. Zoo Yrbk 6, 184-187.

Schaller, G. (1967) The Deer and the Tiger. University of Chicago Press, Chicago.

Schaller, G. (1972) The Serengeti Lion. University of Chicago Press, Chicago.

Schmidt, A.M., Nadal, L.A., Schmidt, M.J. \& Beamer, N.B. (1979) Serum concentrations of oestradiol and progesterone during the normal oestrous cycle and 
early pregnancy in the lion (Panthera leo). J. Reprod. Fert. 57, 267-272.

Shille, V.M., Lundstrom, K.E. \& Stabenfeldt, G.H. (1979) Follicular function in the domestic cat as determined by estradiol-17 $\beta$ concentrations in plasma: relation to estrous behavior and cornification of exfoliated vaginal epithelium. Biol. Reprod. 21, 953-963.

Seal, U.S., Plotka, E.D., Smith, J.D., Wright, F.J., Reindl, M.J., Taylor, R.S. \& Seal, M.F. (1985) Immunoreactive luteinizing hormone, estradiol, progesterone, testosterone, and androstenedione levels during the breeding season and anestrus in Siberian tigers. Biol. Reprod. 32, 361-368.

Ulmer, F.A. (1966) Voices of the Felidae. Int. Zoo Yrbk 6, 259-262.
Verhage, J.G., Beamer, N.B. \& Brenner, R.M. (1976) Plasma levels of estradiol and progesterone in the cat during polyestrus, pregnancy and pseudopregnancy. Biol. Reprod. 14, 579-585.

Wildt, D.E., Platz, C.C., Chakraborty, P.K. \& Seager, S.W.J. (1979) Oestrous and ovarian activity in a female jaguar (Panthera onca). J. Reprod. Fert. 56, 555-558.

Wildt, D.E., Seager, S.W.J. \& Chakraborty, P.K. (1980) Effect of copulatory stimuli on incidence of ovulation on serum luteinizing hormone in the cat. Endocrinology 107, 1212-1217.

Received 16 February 1987 